\title{
Similar, Yet Different: The Conscription Issue in Australia and New Zealand, 1916-17
}

\author{
JOAN BEAUMONT
}

\begin{abstract}
Australia and New Zealand came to World War One with similar political trajectories, and their experience and memory of the war had much in common. However, on the key issue of conscription for overseas military service, they diverged. This article considers possible explanations for this difference. As others have noted, whereas New Zealand Prime Minister William Massey could be confident of a parliamentary majority, the early political power of the labour movement in Australia forced his Australian counterpart, W. M. Hughes, to take conscription to a popular vote - a forum in which the performance of politics and dissent took an unpredictable form. Beyond this, Hughes's chances of gaining consent for conscription were compromised by the timing of the conscription campaigns in Australia-some critical months later than in New Zealand-his personal political style and his failure to craft a scheme of conscription that could secure the majority consent that the more adroit Massey achieved in New Zealand.
\end{abstract}

The Australian commemoration of the centenary of World War One from 2014-18 focused largely on battles. In particular, prominence was given to those battles where Australians were the victims of poor leadership and command (such as Gallipoli and Fromelles), or in which they supposedly made a major contribution to Allied victory over the Central Powers (VillersBretonneux and Amiens). Generally, less public attention was paid to those events on the home front that were arguably of greater importance in Australian political history: the two referenda about conscription for overseas service held in October 1916 and December 2017. These remarkable events not only manifested the power of participatory democracy under draconian wartime constraints, they also polarized Australian society along fault lines that would endure for decades. These referenda were also unique. No other belligerent country held a popular vote on an issue of such central importance to the war effort.

The conscription campaigns have attracted considerable scholarly attention, initially from that generation of Australian historians for whom conscription gained a particular personal urgency during the Vietnam War. ${ }^{1}$ When a man's fate hung on a birthday ballot, the 1916-17 debates about whether the state had the right to force a man to kill acquired an acute salience. The role of women opposing conscription also became of interest as feminist scholars entered the academy, in the 1980 s especially. ${ }^{2}$ More recently, a new wave of scholarly interest in the subject has been generated by the centenary of World War One, an anniversary that Australian official agencies and media promoted relentlessly. ${ }^{3}$

Yet despite this ongoing interest in the subject, one question still rewards further investigation: how it was that the opposition to conscription for overseas service triumphed in Australia? It is common to speak of the conscription votes of 1916 and 1917 as being "lost." However, a useful reframing of the question is: how and why did the anticonscription vote win? How was it possible for the voices of dissent to be so powerful that Australia, alone of all countries in the British Empire, failed to adopt conscription? This is not a case of special pleading for 
Australian exceptionalism - a tendency that Australian military historians are often prone to manifest - but rather a call to consider what we can learn from comparative history about the capacity of wartime dissent to be expressed in different political cultures. Comparative analyses of the conflict over conscription are relatively rare, and those that include Australia are rarer still. ${ }^{4}$ This paper therefore considers how the conscription issue unfolded in Australia and New Zealand: two Dominions whose political cultures and wartime experiences shared much in common, and yet whose histories on the question of conscription were very different.

\section{Shared Histories?}

As the acronym Anzac indicates, the Australian and New Zealander experience of World War One on the battlefront had much in common. The first troops from the two countries sailed together in the convoy leaving Albany in late 1914 and formed the Australian and New Zealand Army Corps soon after arriving in Egypt. These Anzacs landed within hours of each other at Gallipoli on 25 April 1915, and over the following months maintained a precarious hold on the heights above the beach. In the August offensive on Gallipoli they fought battles that would become iconic in their respective national memories: the Nek and Lone Pine, for Australians; and Chunuk Bair, for New Zealanders. With the withdrawal from Gallipoli, the Australian and New Zealand mounted infantries continued to serve together in the long campaign against Ottoman forces in Palestine. On the Western Front, the paths of the two Dominion forces diverged somewhat, with the Australians eventually forming their discrete Corps, but such was the impact of the Gallipoli battles of 1915 that that two countries came to share the mythologized narrative, the Anzac legend, which continues to play a major role in national memories today.

Australia and New Zealand also came to the war with very similar political trajectories. Not only had they both inherited from Britain the political and legal institutions of the Westminster system of government; there had also been a remarkable cross-fertilization of the two political and industrial elites in the years before the war. In what has been described by Melanie Nolan as "a perennial exchange," Australians and New Zealanders had flowed back and forth in successive waves across the Tasman. In 1911, three years before the outbreak of war, there were nearly 32,000 New Zealand-born in Australia and 50,000 Australian-born in New Zealand. ${ }^{5}$ The respective populations at this time were fewer than 5 million for Australia and 1.1 million for New Zealand. Even more significant than these raw numbers was the presence of Australian-born men in New Zealand's labour movement. From 1919-39 the New Zealand Labour Party was led by Australian-born socialists, including the militant socialist, Harry Holland, who edited the labour newspaper the Māoriland Worker from 1913 to 1918. Notably, when the New Zealand Labour Party formed its first national government in 1935, the Cabinet included five Australian-born men. ${ }^{6}$

Yet we should not assume from these trans-Tasman links that Australia and New Zealand had "one history but two historiographies," as has sometimes been argued. ${ }^{7}$ New Zealand chose not to join the Australian federation in 1901, a decision that has been tagged as a movement by New Zealand "away from the informal Tasman world," and the manifestation of an evolving sense of a New Zealand identity in which Australia served as a benign "other." the strong push for trans-Tasman fraternalism in the trade union movement faded in 1913 when the Australian unions, under the influence of Billy Hughes, failed to come out in support of the Waihi miners' strike. ${ }^{9}$ Moreover, although the Australian and New Zealand governments responded to the outbreak of war in August 1914 in very similar ways, embracing imperial loyalty and rapidly raising volunteer expeditionary forces, the manner in which the issue of 
conscription played out in the next two years confirms that New Zealand and Australia were, to quote Marilyn Lake, two countries with two histories. ${ }^{10}$ Indeed, as Steven Loveridge has observed, "the Great War advanced multiple trans-Tasman identities. . . . Language and imagery that evoke[d] association, perhaps even a shared identity, developed alongside language and imagery tagged to a distinct conception of self, even staunch dissociation.",11

How do we explain the divergence of the two countries on the critical issue of conscription? Given the multiplicity of variables at play, it is difficult to give a definitive answer, but three issues seem to have been key. The first - a variable that has long been acknowledged as important - was the respective power of the labour movement in the two countries, and the way in which this dictated the forums in which conscription was debated and the associated politics of performance. The other two explanations speak more to contingency and agency: one is the timing of the conscription debates, especially in 1916; and the second, the leadership styles and skills of the two Prime Ministers, Hughes and William Massey.

\section{The Power of Labour}

In 1914, Australia and New Zealand were two of the most highly unionised countries in the world. The number of registered unions in New Zealand had risen from 109 with a total membership of 27,640 in 1904, to 322 unions with a total membership of 60,622 in $1912 .{ }^{12}$ In Australia, trade union membership grew from under 100,000 in 1901 to well over half a million at the outbreak of war. ${ }^{13}$ With the exchange of personnel across the Tasman, both labour movements had a similarly complex ideological texture. ${ }^{14}$ They accommodated, at one end of the spectrum, a mix of pragmatic socialism and English-style liberalism, which involved a willingness to work with the emerging regulatory institutions of arbitration and conciliation, and, at the other end, militant socialism, anarcho-syndicalism and an advocacy of direct action, as espoused particularly by the Industrial Workers of the World. ${ }^{15}$ Given this complexity, support for arbitration was uneven and conditional, and many unionists continued to place faith in direct action even though this had had a mixed record of success and bitter defeat in the immediate prewar years, notably during the 1909 strike at Broken Hill, and at Blackball in 1908 and Waihi in 1913.

Yet, if there were similarities, there were also important differences between the two labour movements. One was that of scale. The New Zealand movement was smaller and thus lacked the resources and critical mass of its Australian counterpart. More importantly, labour in New Zealand had been slower to make the transition to being a political force with strong organisational structures across the country. Certainly, there were parliamentarians in Wellington endorsed by the trade unions from the early 1890 s on, but in a political system noted for its "intimacy," the emergence of labour was blunted by the pragmatic alliance of labourites with Liberals, most notably, under "King Dick" Seddon (Prime Minister 18931906). ${ }^{16}$ Although Seddon's record as a workers' champion has been debated, his recent biographer has concluded that "pragmatism and genuine concern for working people's welfare .. . characterised his long career [and] he achieved far more for working men and women than pro-Labour historians have conceded." $" 17$

In Australia, by contrast, a more fluid political landscape provided the conditions in which political labour movements emerged in the aftermath of the bitter defeat in the 1890 strike and the accompanying economic depression. As early as 1891, Labor candidates in the New South Wales (NSW) election had won 35 of 141 seats and held the balance of power. In 1899 Labor formed a minority government in Queensland, the first in the world. The development of 
political labour in other states was less developed, but the elements of a political party structure were emerging across Australia. Federation in 1901 provided the occasion-indeed, the necessity - for Australian labour to create a national organisation. This, too, enjoyed early electoral success. In 1904 the Australian Labor Party (ALP) formed a minority Commonwealth government, the first Labor-led national government in the world. By 1910, it held sufficient seats in the federal lower house to form a majority government. Then, in the double dissolution election of September 1914, held one month after the war began in Europe, the ALP won 42 of 75 seats in the Representatives and 31 of 36 seats in the Senate.

In contrast, New Zealand labour's attempts from about 1906 on to create a unified political movement floundered. Despite growing anxiety about the loss of ground by the Liberals to the farmers' Reform Party, which came to power in 1912, and disillusionment with the arbitration system and declining wages, New Zealand labour remained a mélange of competing regional power bases, rival workers' federations and small political parties. Despite two efforts in 1912 and 1913, unity "remained imperfect" with disagreements over issues such as defence policy and military training. ${ }^{18}$ Only in July 1916 did the New Zealand Labour Party finally come into existence, when conscription helped provide a basis of unity. ${ }^{19}$ Even then, various groups, such as the Social Democrats in Christchurch, refused to join the new party and ideological and factional tensions continued. ${ }^{20}$

Australian labour, too, had its own - and, as it proved, disastrous - internal tensions, but it began the war as "by far the strongest labour-based party in the world." ${ }^{21}$ However, as Robin Archer has argued, this political strength had two, contradictory, effects. On the one hand, the precocious political strength of the ALP more or less silenced dissent from the labour movement at the outbreak of war. In contrast to the labour leaders in the United Kingdom and Europe, who anguished over whether to support their governments, the Labor Opposition leader Andrew Fisher coined the famous phrase at the height of the July 1914 diplomatic crisis that Australia would support Britain "to the last man and last shilling." He was in the middle of a federal election campaign and, it seems, was keen to deny his conservative opponents any chance to cast doubt on Labor's patriotism and imperial loyalty and its eligibility to lead the nation in war. ${ }^{22}$ Thus, the radical strand of labour opinion in Australia that, like its New Zealand counterpart, saw the "real war" as a struggle between capital and labour was marginalised at a critical moment of decision making.

However, the very strength of political labour that marginalised dissent in 1914 proved to be their leader Hughes's undoing when the issue of conscription came to be debated from late 1915 on. Logically, the parliamentary majority enjoyed by Hughes (who became Prime Minister in October 1915) should have been an asset when it came to passing legislation to amend the Defence Act (this legislation allowed only volunteers to be deployed on overseas military service). But the labour movement was deeply divided on the question of conscription. Not only did the unions fear that military conscription would be a precursor to industrial conscription; as well, they were deeply distrustful of a government which had failed to curb the inflation in the prices of essential commodities caused by the war and which had reneged in late 1915 on a commitment to hold a referendum by which the Commonwealth government would have gained increased powers over the economy. ${ }^{23}$ Fuelling this grievance was a deeper division as to whether the parliamentary Labor Party owed primary loyalty to its working class base or to the nation as a whole, and whether the parliamentary caucus should be dictated to by the local party organisations. 
The very power of Hughes's political base then blocked the path that other governments of the Empire - Canada, New Zealand and the United Kingdom - took: that is, the introduction of conscription by legislation. This is not to say that the legislative path in any of these countries was easy. In Canada, Robert Borden introduced conscription in the face of extensive public resistance, especially within farming communities and French-speaking Quebec. ${ }^{24}$ In New Zealand, too, the passage of the Military Service Bill through parliament in May-June 1916 triggered passionate debate and opposition both within and outside parliament. In the preceding months, 85 organisations, including all Trades and Labor Councils (except Otago), rejected conscription unless it was accompanied by conscription of wealth; and when the Bill came to parliament, labour parliamentarians tried to block the legislation at various divisions. ${ }^{25}$ However, Massey had a majority that would support conscription. This was thanks to the coalition that his Reform Party had formed with the Liberals in August 1915 and to the parliamentary weakness of labour. Although all bar one of the five labour parliamentarians voted against the Bill on 9 June 1916, Massey had a majority of forty. There was something of a legislative impasse over the question of religious objectors, which meant that the Bill commuted between the two houses of parliament, but it finally became law on 1 August 1916.

For Hughes, however, such a parliamentary path was blocked. A Bill seeking to amend the Defence Act would probably have been passed in the Representatives, since the Liberal opposition would vote for it, but in the Senate the large Labor majority would almost certainly have rejected it. Hughes might have tried to introduce conscription by executive action using the emergency powers of the War Precautions Act, but there were doubts as to the legality of this. Hughes had advice that a regulation under this Act could not override an express prohibition in the Defence Act, and in any case, both houses of parliament had the power to disallow a regulation under the Act. ${ }^{26}$

So Hughes decided on a national plebiscite, hoping thereby to secure a mandate with which to outflank his own Labor Party and the powerful industrial movement. He was the only imperial leader who was forced to put this deeply contentious matter to a direct popular vote. Of course, he did this because he thought he would win. When he returned in late July 1916 from a long visit to the London, he received a rapturous reception, being feted as a Dominion leader who had tweaked the nose of the imperial government - although somewhat ominously, he was also pilloried by the labour press for being "duchessed" by the British establishment. Moreover, Hughes had prodigious powers of oratory and extraordinary energy, his poor heath notwithstanding, and he had a range of executive powers, including heavy censorship, with which he thought he could mute the critiques of conscription.

\section{The Implications of a Popular Vote}

However, there were significant risks involved in seeking popular endorsement for conscription. For one thing, Hughes had to fight a national campaign without his natural power base. Since the federal parliamentary party did not pass a formal resolution on conscription, many members of the caucus became reluctant to back Hughes for fear of losing their future preselection. ${ }^{27}$ Yes, Labor was in power in every state, bar Victoria, but the state executives of the party failed in the first weeks of September to respond to all of Hughes's determined entreaties. Then, on 14 September, the first of a succession of ministers to resign on the issue, Frank Tudor, left the federal cabinet. The following day the NSW Executive of the Labor Party expelled Hughes and withdrew endorsement for the next state elections from the Premier of New South Wales, William Holman, and three other members of state parliament who supported conscription. All of this happened even before the Bill to conduct the referendum 
was narrowly passed on 21 September and the six-week campaign for the vote on 28 October began. Holman would come out in support of conscription, but in Queensland, the Premier T. J. Ryan, leader of the state's Labor government, mobilised all his state power apparatus to oppose Hughes - something that would have dramatic implications for the 1917 campaign, when Ryan and Hughes engaged in a cat-and-mouse game about the Premier's attempts to read into the Hansard of the Queensland Legislative Assembly sections of a speech he had made at an anticonscription rally in Brisbane but which the censor had cut before publication. ${ }^{28}$ Bizarre though this episode seems it retrospect, it points to a key difference with New Zealand: namely, that under the Australian federal system there could be opposition to conscription that could access the resources of state power.

Not only did Hughes campaign without a secure base in the ALP, but he found the formidable Labor press lined up against him. Most notably, he confronted the editor of The Australian Worker, Henry Boote, a master of words, who progressively made the organ of the Australian Workers' Union (AWU) his "personal propaganda instrument." ${ }^{29}$ Each week, Boote penned editorials railing against the iniquities of conscription while commissioning cartoons that played brilliantly on the fears of working-class Australian men-unaffordable food, loss of jobs to female or Asian workers, the vulnerability of married men to conscription and the treachery of the turncoat Hughes. Boote also brilliantly elevated the anticonscriptionist cause beyond class interests to the high moral ground of values and principle. As he said on 7 September, "Society goes outside its moral jurisdiction when, against his will, it compels the individual to caress another; or when, against his will, it compels the individual to fight another." 30

There were, as it happens, New Zealand counterparts to Boote and the Australian Worker, in the forms of Henry Holland and the Maoriland Worker. However, although Holland was probably a more doctrinaire socialist than Boote and had similar drive and will, he seems to have lacked the other's rhetorical edge. He evidenced "the marks of a self-taught mind: the compilation of a massive amount of knowledge without selective rigour or analytical penetration." His socialism was "at heart emotional, not intellectual," and his uncompromising view that world revolution was at hand lacked some of the canny pragmatism of the Australian Worker. ${ }^{31}$ To add to this, the New Zealand press may have lacked the stridency that came from fratricidal betrayal. Massey, the farmer, was easily cast as a class enemy but Hughes was one of the labour movement's most prominent leaders. His change of heart now made him a Judas, a rat.

Of course, we cannot know how much the Australian Worker influenced the outcome of the conscription campaign. However, its reach was considerable. The AWU membership in 1916 was around 100,000 and all members in NSW, Victoria, South Australia and Tasmania received a free copy of Australian Worker as part of their membership. ${ }^{32}$ Queensland and Western Australia had separate newspapers, the Worker and Westralian Worker respectively, but there was much sharing of content between the papers. Perhaps the Australian Worker did not reach all AWU members, as many were itinerant, but the paper was widely read by non-AWU members. Nonmembers had to pay one penny, at a time when the minimum wage was around £2/6/-. ${ }^{33}$ For those who did not read the Australian Worker in depth, there were the "extras" the paper's Sydney office pumped out in 1916: an astonishing 5 million pamphlets and leaflets; half a million "How to Vote No" cards; 100,000 extra copies of the Australian Worker; a quarter of a million stickers; 25,000 posters; and much else. In this way, the paper provided a powerful counterweight to the mainstream press, all of which came out in 
favour of conscription. It surely contributed to the mass mobilisation by which, to cite Frank Bongiorno, a virtual army of men and women in labour were empowered. ${ }^{34}$ It may also have encouraged any voters who were vacillating about whey they stood on the question of conscription to vote No.

This points to the more general risk that the resort to a popular vote posed for Hughes: namely, that plebiscites often acquire an unpredictable dynamic of their own. They take debate about a contentious issue from the relatively controlled environment of the legislature, with its limited number of actors, into the public domain, with its multiple players and multiple audiences. Moreover, if the campaign is long - and the Australian conscription campaign of 1916 lasted for around two months - the debates can slip out of the control of the politicians who initiate them. Direct democracy, then, has a very different power dynamic to representative democracy. In a plebiscite, the performance of politics is given full rein in the public sphere and the politics of dissent take an inherently unpredictable form.

So it was in 1916. Not only did the conscription campaign give voice to a plethora of issues, reaching well beyond the military need for compulsion, but the contending arguments were rehearsed on a very public stage. The restrictions imposed by the Hughes government on freedom of assembly and freedom of speech were substantial, but the anticonscriptionists were still able to hold huge public meetings across Australia, meetings that were marked by all manner of intimidation: heckling, booing, chanting, counting the speaker down, pelting of speakers with mud and rotten eggs, invading of speaker platforms, the breaking of banners, the singing of the Red Flag, the burning of effigies of Hughes and physical assaults. In this public performance of politics, dissent was given a dramatic visibility and the power relations that underpinned the confrontation over conscription were vividly exposed. As Jeffrey C. Alexander has argued: "The distribution of power in society - the nature of its political, economic, and status hierarchies, and the relations between its elites-profoundly affects the performance process." ${ }^{35}$ So, too, does performance affect perceptions of power. The conscription rallies thus not only gave physical form to the confrontation between the agencies of the state and its opponents, fuelling perceptions of an almost authoritarian state; they also made visible the scale of the remarkable grassroots mobilisation. Given that voting was at the time voluntary, this powerful challenge to the state may have encouraged a higher participation rate. The turnout rates for the 1916 referendum was 82.8 percent; for $1917,81.3$ percent. $^{36}$

\section{The Question of Timing}

Vacillating Australians may also have been swayed to vote by the timing of the conscription votes - a variable rarely acknowledged in histories of this issue. New Zealand, like the United Kingdom, debated and ultimately resolved the question of conscription in the first half of 1916. At this time there was still some possibility of extracting political capital from the Gallipoli campaign, which for all its failures had generated a euphoric Dominion pride, most evident in the commemoration of the first anniversary of Anzac Day in both countries as well as in London. In these early months of 1916, too, the New Zealand government, like the British Asquith government before it, was able to capitalise on its recent attempts to test the limits of voluntaryism. In 1915 a National Registration Act had obliged all New Zealand men between 17 and 60 to register. Many had not; and when all those between 19 and 45 were asked to indicate whether they were prepared to enlist or undertake necessary civilian work, nearly 60 percent said they were willing to serve overseas. A substantial minority would not volunteer for any kind of service. ${ }^{37}$ Massey therefore was able to mount a strong case that conscription was justifiable because voluntaryism had failed. 
The Hughes government made similar efforts in the second half of 1915 to maximise voluntary enlistments through a War Census, which collated data on potential recruits as well as personal wealth, and a Call to Arms that sought to exploit patriotism, idealism and national pride to entice more men to volunteer. But, instead of maintaining such momentum as this generatedand it also created some backlash, coinciding as it did with the cancellation of the prices referendum-Hughes left Australia in late January 1916 for London. In the six months that he was overseas, the Easter uprising occurred in Dublin and the British authorities summarily executed leaders of the rebellion. Although the impact of the Irish-Catholic vote on the subsequent conscription vote continues to be debated, Hughes came to see the British failure to resolve Home Rule as a huge political liability in Australia, where Irish-Catholics formed almost a quarter of the population in Australia. In New Zealand, in contrast, most Irish were Protestants, the Irish-Catholic population was smaller and the debates were less affected by sectarianism. $^{38}$

Hughes's long absence in London also gave the opponents of conscription time to mobilise. There were, in fact, many within the trade unions who were inclined to support conscription. However, in early 1916, an oligarchic executive council of the major trade union, the Australian Workers' Union, forced pro-conscriptionists out of leadership positions. ${ }^{39}$ In early 1916, too, the critically important state labour organisations, such as the Sydney Trades and Labor Council, and the Melbourne Trades Hall Council, as well as the annual conferences of the state Labor parties in Victoria, New South Wales and Queensland, all voted to oppose conscription. They were soon to be joined by South Australia and Tasmania. Only the Western Australian party refused to commit itself. Then, at a special All Australia Trade Unionism and Conscription Congress in May 1916, an overwhelming majority declared its "uncompromising hostility" to conscription. ${ }^{40}$

Finally, Hughes's absence from the home front coincided with the launching of the Battle of the Somme on 1 July. This soon involved the first major commitment of Australians to the Western Front and within less than eight weeks the Australian Imperial Force had suffered some 28,500 casualties. Of course, these massive casualties supposedly justified the military case for conscription. But they also invested the popular debate about conscription with the toxic mix of mass grief and despair about a war that seemed beyond the control of any politician or military commander. In a classic case of misdirected aggression, these emotions were deflected onto opponents at home. Similarly, when Hughes again sought to win popular support for conscription in late 1917, the campaign was charged with emotional dynamite because it was held at the end of the Third Battle of Ypres or Passchendaele, a battle that even at the time was recognised to be the acme of futile attrition.

What might have been the result if Hughes had held the referendum in the first half of 1916 and not the second? What if he had stayed at home in early 1916 to push this critical issue through? Massey too had been invited as a Dominion leader to come to London for consultations, but he sailed for Britain only in mid-August 1916 after he had carefully shepherded the Military Service Act through parliament. Moreover, in what was a matter of luck rather than calculation, Massey was able to do this before the New Zealand Division was committed to the Battle of the Somme on 15 September 1916. Speculation about the impact of timing is of course counterfactual history. Alas, we will never know how many Australians who chose to vote No had lost a family member on the Western Front between July and October 1916. Perhaps all we can conclude with confidence is that Hughes's prolonged absence made it even more difficult for him to manage a debate that was rapidly spiralling out of control. 


\section{Leadership Styles}

A related issue that may have shaped the differing outcomes in Australia and New Zealand was the leadership provided by Hughes and Massey. No matter where the battle over conscription was fought out across the British Empire, it demanded that political leaders manifest high-level skills of negotiation and compromise. These were not qualities that Hughes possessed in abundance. In many ways, he was a formidable politician, bringing to the defence of Australian interests, as he saw them, an almost fanatical passion and energy. But as the anticonscriptionist campaign gathered strength, Hughes became increasingly confrontational, presumably because he saw his personal and political authority challenged. In particular, he resorted to using the powers of the War Precautions Act in a partisan manner, to restrict the freedom of speech, assembly and press of his political opponents. That said, with one notable exception - that is, the imprisonment of the leaders of the Industrial Workers of the World in late 1916 on trumpedup charges of arson and treason - the use of state power against the left in Australia was not as draconian as in New Zealand. In November 1916, Boote was fined $£ 16$ with costs. But when the anticonscriptionist campaign got a new lease of life in New Zealand, in late 1916, "almost half the effective platform propagandists of the Labour Movement"-leaders such as Patrick Webb, Frederick Cooke, Robert Semple, Peter Fraser, John Thorn and Thomas Brindle-were imprisoned with sentences of up to a year, in some cases with hard labour. ${ }^{41}$ (This was despite the preference of the authorities, seeking "as wide a legitimation as possible," to use the minimum of state compulsion and coercion to sustain the war effort. ${ }^{42}$ ) The treatment of religious, and particularly conscientious, objectors in New Zealand was also particularly harsh. As Peter O'Connor has argued, New Zealand was "less tolerant than the United Kingdom where legislation allowed for conscientious as well as religious objection," and the criteria for exemption from military service in New Zealand were so restrictive, and in certain respects, arbitrary, that by the end of 1917 the great majority of objectors-possibly, 208 - had been imprisoned. ${ }^{43}$ Meanwhile, in the most celebrated case, fourteen conscientious objectors were classed as "defiant objectors" and were sent overseas in July 1917, where some were subjected to brutal military punishments and incarceration. ${ }^{44}$

Yet if there were limits to Hughes's exercise of power, he projected an authoritarian style allowing his critics to cast him in the mould of the very Prussian militarism that Australia was purportedly fighting. In particular, Hughes suffered significant political damage when in the middle of the 1916 conscription campaign he used such powers as he did have under the Defence Act to call up eligible men for military training. Supposedly, this measure was meant to ensure that there would be a body of troops partially trained and ready to embark in the event of the referendum approving conscription. However, it seemed a preemptive and arrogant prejudging of the result of the referendum.

In contrast, Massey had a somewhat deceptive "bluff rustic persona" but he was an astute politician. ${ }^{45}$ Not only did he manage to develop consensus within the national government that the Reform Party and Liberals formed in August 1915- a coalition that required that cabinet decisions be unanimous - but with the assistance of his effective Minister for Defence, James Allen, Massey presented to New Zealanders a system of military service that was politically tolerable. The Military Service Bill of 1916, which contained 47 clauses (as compared to 8 in the comparable British Bill), was shaped around the principle that volunteering would continue to be the preferred means of recruitment. Conscription would only be introduced if a particular military district did not meet its quota. In that instance, men from that district would be conscripted by a ballot to make up the shortfall. It was a masterly compromise which "read the public mood with adroitness." 46 As Paul Baker has put it, the scheme meant that "the 
application of conscription would depend not upon a Government decision, but upon a shortage of volunteers - in effect, a popular decision." ${ }^{47}$ In addition, men were conscripted by monthly ballot, not, as elsewhere, en masse by a preestablished category of eligibility. Appeals for exemption from service (be they on the grounds of employment or beliefs) were largely administered by independent bodies or government departments other than Defence. Importantly, too, Massey circumvented the delicate question of Māori loyalty by initially imposing conscription on Pākehā only. ${ }^{48}$ This changed in June 1917 but even then, Allen, who administered the scheme with considerable sensitivity, decided to apply it only to the WaikatoManiapoto land district, as other iwi supposedly met their obligations by volunteering earlier. ${ }^{49}$ In the event, there was continuing resistance from the Waikato, who had a tradition of nonviolence after the 1860s wars and linked conscription to demands for the restitution of their lost lands. Ultimately, only 552 Māori men were called up. ${ }^{50}$ Yet, despite this Māori resistance, and that of a small number of conscientious objectors, the New Zealand scheme met what Margaret Levi has called "the minimal terms of the democratic conscription bargain," in that the government conscripted "according to some legislated and relatively equitable formula" and thereby elicited "the contingent consent" of the majority of the New Zealand population. ${ }^{51}$

The carefully crafted scheme of conscription in New Zealand was a dramatic contrast to what Hughes put to the Australian people. On 28 October 1916 Australians were asked: "Are you in favour of the Government having, in this grave emergency, the same compulsory powers over citizens in regard to requiring their military service, for the term of this war, outside the Commonwealth, as it has now with regard to military service within the Commonwealth?" It was an opaque question that required a level of trust in government that many Australians were unwilling to give. Hughes seems to have recognized this, and when he put the question of conscription to the votes again in December 1917 he proposed something akin to the New Zealand scheme. But it was too late. The 1917 campaign was probably unwinnable. Not only had there been nearly 77,000 further Australian casualties in more ultimately indecisive battles in 1917, but the No campaign was given additional force by Ryan and a new major player, the Catholic Archbishop of Melbourne, Daniel Mannix. Although his influence on the national vote has been overestimated, Mannix can perhaps take some of the credit for Victoria's vote changing from Yes in 1916 to No in 1917.

Hughes's failure to offer a more politically palatable version of conscription to the Australian people might be attributable to his chaotic style of governance. His cabinet procedures verged on the dysfunctional and he struggled to delegate. But his Minister of Defence, George Pearce, was less able than Massey's Allen and the demands of the Australian Imperial Force for reinforcements were far greater than those of the New Zealand Expeditionary Force. By early 1916 Australia was committed to maintaining five - even, it was hoped for a while, sixdivisions in the field. The New Zealand government, in contrast, husbanded its manpower resources, limiting its commitments to one large division on the Western Front and a Mounted Rifles Brigade in Palestine. ${ }^{52}$ This arguably gave Massey the flexibility to introduce a less invasive form of conscription, with the result, historian Chris Pugsley has claimed, that "public opinion was not split asunder with the political turmoil and dissent that was the legacy of the ill-planned and insufficiently thought-through reinforcement procedures of Australia and Canada." 53 


\section{Conclusion}

In conclusion, it seems that any explanation of the victory of the anticonscription vote in Australia in 1916 and 1917 needs to incorporate structure, contingency and individual agency. Given that the vote for No in Australia in 1916 won by only a small margin of 72,476 votes, or 3.2 percent of the valid votes cast, it would be unwise to dismiss the significance of timing and leadership styles ${ }^{54}$ Given that the whole apparatus of the state and most of the media had been campaigning for Yes, Hughes had a chance of winning, at least in 1916. However, in some critical respects he misplayed his hand. Had he attached less importance to imperial matters and considered more closely in 1916 the carefully crafted and politically palatable scheme that his New Zealand counterpart was introducing across the Tasman, he might perhaps have persuaded enough Australians to consent to conscription.

However, the unique and precocious strength of the labour movement within Australia ultimately played a decisive role. While Massey could rely on a solid parliamentary majority, Hughes had to put the matter of conscription to the vote with all the political risks that this entailed. At the same time the sheer scale of the extraparliamentary Australian labour movement provided the anticonscription movement with the organizational structure to mobilize mass opposition and, through the labour press, to give voice to powerful dissent. ${ }^{55}$ The labour movement, of course, was not the only source of opposition to conscription: the anticonscriptionist movement was a broad church, including middle-class liberals, pacifists and those for whom it was morally offensive to force men to kill. But the individual voice could be easily silenced. The labour movement of Australia-divided, fractured and profoundly damaged though it was by the conscription debate - could not. As the president of Political Labor League in NSW said at a public meeting in Sydney Town Hall, "You will see here no Prime Ministers, no Premiers, and no Lord Mayors, but you will see the people's representatives, who will tell you there is no need of conscription in Australia." 56

\footnotetext{
${ }^{1}$ Much of the early research was regionally based: Ina Bertrand, "The Victorian Country Vote in the Conscription Referendums of 1916 and 1917: The Case of the Wannon Electorate," Labour History 26 (1974): 19-31; P. M. Gibson, “The Conscription Issue in South Australia, 1916-1917," University Studies in History 4, no. 4 (1963-64): 47-80; Alan D. Gilbert, "The Conscription Referenda, 1916-17: The Impact of the Irish Crisis," Historical Studies 14, no. 53 (1969): 54-72; K. S. Inglis, "Conscription in Peace and War, 1911-45," in Conscription in Australia, ed. Roy Forward and Bob Reece (St Lucia: University of Queensland Press, 1968), 22-65; A. R. Pearson, "Western Australia and the Conscription Plebiscites of 1916 and 1917," RMC Historical Journal 3 (1974): 21-27; J. R. Robertson, "The Conscription Issue and the National Movement in Western Australia, June 1916December 1917," University Studies in Western Australian History 3, no. 3 (1959): 5-57. A very influential piece of research from the early 1980s was Glen Withers, "The 1916-1917 Conscription Referenda: A Cliometric Re-appraisal," Historical Studies 20, no. 78 (1982): 36-47.

2 Judith Smart, "The Right to Speak and the Right to be Heard: The Popular Disruption of Conscriptionist Meetings in Melbourne, 1916," Australian Historical Studies 23, no. 92 (1989): 20319; Hilary Summy, "Margaret Thorp and the Anti-Conscription Campaign in Brisbane 1915-1917," Hecate 32, no. 1 (2006): 59-76; Joy Damousi "Socialist Women and Gendered Space: Anticonscription and Anti-war Campaigns of 1914-1918," Labour History 60 (1991): 1-15.

${ }^{3}$ Notably, Robin Archer et al., eds, The Conscription Conflict and the Great War (Clayton, Victoria: Monash University Publishing, 2016). This is the only book-length treatment on the subject of conscription since Leslie C. Jauncey's classic, The Story of Conscription in Australia (London: George Allen \& Unwin, 1935). The conscription campaigns were given considerable coverage in Joan
} 
Beaumont, Broken Nation: Australians in the Great War (Sydney: Allen \& Unwin, 2013), especially 219-48 and 374-89.

${ }^{4}$ A useful summary of the literature can be found in Robin Archer, "Stopping War and Stopping Conscription: Australian Labour's Response to World War I in Comparative Perspective," Labour History 106 (2014): 44-46.

${ }^{5}$ Melanie Nolan, "Personalizing Class Conflict Across the Tasman: The New Zealand Great Strike and Trans-Tasman Biography," Journal of New Zealand Studies NS18 (2014): 119.

${ }^{6}$ Nolan, "Personalizing Class Conflict," 130.

${ }^{7}$ Philippa Mein Smith, "New Zealand Federation Commissioners in Australia: One Past, Two Historiographies," Australian Historical Studies 34, no. 122 (2003): 305-25. For the two historiographies, see Philippa Mein Smith and Peter Hempenstall, "Rediscovering the Tasman World," in Remaking the Tasman World, ed. Philippa Mein Smith, Peter Hempenstall, and Shaun Goldfinch (Christchurch: Canterbury University Press, 2008), 13-16.

${ }^{8}$ Steven Loveridge, "The 'Other' on the Other Side of the Ditch? The Conception of New Zealand's Disassociation from Australia," Journal of Imperial and Commonwealth History 44, no. 1 (2016): 7374.

${ }^{9}$ Nolan, "Personalizing Class Conflict," 122.

${ }^{10}$ Lake, Presidential address to the Australian Historical Association, cited in Nolan, "Personalizing Class Conflict," 122.

${ }^{11}$ Loveridge, "The 'Other' on the Other Side," 71.

${ }^{12}$ Noel Woods, Industrial Conciliation and Arbitration in New Zealand (Wellington: Government Printer, 1963), 90.

${ }^{13}$ Ian Turner, Industrial Labour and Politics: The Labour Movement in Eastern Australia 1900-1921 (Canberra: Australian National University, 1965), 34.

${ }^{14}$ Erik Olssen and Len Richardson, "The New Zealand Labour Movement, 1880-1920," in Common Cause: Essays in Australian and New Zealand Labour History, ed. Eric Fry (Sydney: Allen \& Unwin, 1986), 9; James Bennett, 'Rats and Revolutionaries': The Labour Movement in Australia and New Zealand 1890-1940 (Dunedin: Otago University Press, 2004), 59-65.

${ }^{15}$ For the importance of the influence of English liberalism in the Australian labour movement see Robin Archer, "Labour and Liberty: The Origins of the Conscription Referendum," in Archer et al., The Conscription Conflict, 37-66.

${ }^{16}$ Len Richardson, "Parties and Political Change," in The Oxford History of New Zealand, ed. G. Rice, 2nd ed. (Oxford: Oxford University Press, 1992), 202-03; On "intimacy," see R. S. Milne, Political Parties in New Zealand (Oxford: Clarendon Press, 1966), 2.

${ }^{17}$ On Seddon's relationship with the labour movement see Tom Brooking, Richard Seddon: King of God's Own (Auckland: Penguin, 2014), chapter 11; quotations at kindle version loc 6342, 6831/17665.

${ }^{18}$ Peter Franks and Jim McAlooon, Labour: The New Zealand Labour Party, 1916-2016 (Wellington: Victoria University Press, 2016), 64; Barry Gustafson, Labour's Path to Political Independence: The Origins and Establishment of the New Zealand Labour Party 1900-19 (Auckland: Oxford University Press, 1980), 105.

${ }^{19}$ See, for example, Jack Vowles, "Ideology and the Formation of the New Zealand Labour Party: Some New Evidence," New Zealand Journal of History 16 no. 1 (1982): 46; Franks and McAloon, Labour, 69.

${ }^{20}$ Franks and McAloon, Labour, 71-73.

${ }^{21}$ Archer, "Stopping War," 62.

${ }^{22}$ Archer, "Stopping War," 62.

${ }^{23}$ Beaumont, Broken Nation, 143-45. The labour movement claimed that there should be a conscription of wealth as well as military conscription, but Robin Archer has argued persuasively that this was a slogan adopted for tactical purposes to put conscriptionists "on the back foot" and strengthen the effectiveness of the voluntary system by providing additional resources. There was not, as Nick Dryenfurth has argued, widespread support of a system of dual conscription (Archer, "Labour and Liberty," 61-65). 
${ }^{24}$ On resistance to conscription in Canada, and Quebec's attitude to voluntary recruitment and conscription, see Robert Brown and Donald Loveridge, "Unrequited Faith: Recruiting the CEF 19141918," Canadian Military History 24, no. 1 (2015): 76-80.

${ }^{25}$ Gustafson, Labour's Path to Political Independence, 109-10. For the passage of the Act see Paul Baker, King and Country Call: New Zealanders, Conscription and the Great War (Auckland: Auckland University Press, 1988), 86-95.

${ }^{26}$ Archer, "Stopping War," 58.

${ }^{27}$ Jauncey, The Story of Conscription in Australia, 162.

${ }^{28}$ A good account of this incident can be found in L. F. Fitzhardinge, The Little Digger, 1914-1952, vol. 2, William Morris Hughes, A Political Biography (Sydney: Angus \& Robertson, 1979), 289-96.

${ }^{29}$ Scott Stephenson, "Oligarchy Contested and Interconnected: The New South Wales Labor Party and the Trade Unions from 1910 to 1939" (PhD thesis, Australian National University, 2017), 124. 30 "The Vital Argument," Australian Worker, 7 September 1916.

${ }^{31}$ Patrick O'Farrell, "Holland, Henry Edmund," Dictionary of New Zealand Biography, teara.govt.nz/en/biographies/3h32/holland-henry-edmund. Holland saw conscription as the last desperate hope of a capitalist society seeking, in a revolutionary situation, to avert its destruction: P. J. O'Farrell, Harry Holland: Militant Socialist (Canberra: ANU Press, 1964), 72.

${ }^{32}$ Stephenson, "Oligarchy Contested," 124.

${ }^{33}$ Stephenson, "Oligarchy Contested," 78.

${ }^{34}$ Frank Bongiorno, "Anti-conscriptionism in Australia: Individuals, Organisations and Arguments," in Archer et al., The Conscription Conflict, 79.

${ }^{35}$ Jeffrey C. Alexander, Performance and Power (Cambridge: Polity, 2011), 32.

${ }^{36}$ Murray Goot, "The Results of the 1916 and 1917 Conscription Referendums Re-examined," in Archer et al., The Conscription Conflict, 113.

${ }^{37}$ John E. Martin, "Blueprint for the Future? "National Efficiency' and the First World War," in New Zealand's Great War, John Crawford and Ian McGibbon (Auckland: Exisle, 2007), 518.

${ }^{38}$ Philippa Mein Smith, “The 'NZ' in Anzac: Different Remembrance and Meaning," First World War Studies 7, no. 2 (2016): 195. For a recent analysis of the Irish-Catholic vote in Australia's conscription campaigns, see Goot, "The Results of the Referendums," 136-41.

${ }^{39}$ Stephenson, "Oligarchy Contested," chapter 3.

${ }^{40}$ Archer, "Stopping War," 57-58.

${ }^{41}$ Holland, quoted in Richard Hill, "State Servants and Social Beings: The Role of the New Zealand Police Force in the Great War," in New Zealand Society at War 1914-1918, ed. Steven Loveridge (Wellington: Victoria University Press, 2016), 106-07; Gustafson, Labour's Path to Political Independence, 114-15.

${ }^{42}$ Hill, "State Servants and Social Beings," 109.

${ }^{43}$ P. O'Connor, "The Awkward Ones: Dealing with Conscience 1916-1918," New Zealand Journal of History 8, no. 2 (1974): 132, 126-27.

${ }^{44}$ For an account of two conscientious objectors' treatment, see David Grant, Field Punishment No. 1: Archibald Baxter, Mark Briggs \& New Zealand's Anti-militarist Tradition (Wellington: Steele Roberts, 2008).

${ }^{45}$ Barry Gustafson, "Massey, William Ferguson," Dictionary of New Zealand Biography, teara.govt.nz/en/biographies/2m39/massey-william-ferguson

${ }^{46}$ Hew Strachan, "Foreword," in New Zealand Society, ed. Loveridge, 12.

${ }^{47}$ Baker, King and Country Call, 86.

${ }^{48}$ For discussion of Māori attitudes towards the Great War, see Steven Loveridge and Basil Keane, "Turangawaewae: Māori Relationships with the Great War," in New Zealand Society, ed. Loveridge, 281-96.

${ }^{49}$ For Māori service, see Timothy Weinberg, Indigenous Peoples of the British Dominions and the First World War (Cambridge: Cambridge University Press, 2012), 104-10.

${ }^{50}$ Loveridge and Keane, "Turangawaewae," 294; Hill, "State Servants and Social Beings," 107.

${ }^{51}$ Margaret Levi, "The Institution of Conscription," Social Science History 20, no. 1 (1996): 134-35. 
${ }^{52}$ Although New Zealand was asked in late 1916 to raise a second division, it instead created a fourth Brigade in the existing Division.

${ }^{53}$ Chris Pugsley, The Anzac Experience: New Zealand, Australia and Empire in the First World War (Auckland: Reed, 2004), 70.

${ }^{54}$ Figures from Goot, "The Results of the Referendums," 121.

${ }^{55}$ My conclusions affirm those of Margaret Levi, who has stressed the importance in the defeat of conscription of opponents having organisational and institutional arrangements, as well as the failure of the government to mobilize contingent consent ("The Institution of Conscription," 155-59).

56 "The Great Fight. No! Mr. Hughes," Australian Worker, 28 September 1916. 